\title{
Vulnerability to Sexually Transmitted Infections in women who sell sex on the route of prostitution and sex tourism in Central Brazil ${ }^{1}$
}

\author{
Marcos André de Matos ${ }^{2}$ \\ Karlla Antonieta Amorim Caetano ${ }^{3}$ \\ Divânia Dias da Silva França ${ }^{3}$ \\ Raquel Silva Pinheiro 4 \\ Luciene Carneiro de Moraes ${ }^{5}$ \\ Sheila Araujo Teles ${ }^{6}$
}

\begin{abstract}
Objective: to investigate knowledge on sexually transmitted diseases (STDs), STD-related risk behaviors, and signs/symptoms of STDs among female sex workers (FSWs). Methods: a cross-sectional study was conducted with a probabilistic sample comprising 395 women recruited using a respondent-driven sampling method between 2009 and 2010. The data were collected during face-to-face interviews. Results: most of the participants were young adults, had a low educational level, and had poor knowledge on the transmission paths of the human immunodeficiency virus (HIV). Over one-third of the participants were not able to describe the signs/symptoms of STDs. The prevalence rates of vaginal discharge and wounds/ulcers were $49.0 \%$ and $8.6 \%$, respectively, but $41.7 \%$ of the women had not sought treatment. Conclusion: the results indicate the need for public health policies focusing on the control and prevention of STDs in this population, especially for the FSWs who are active in an important prostitution and sex tourism route in central Brazil.
\end{abstract}

Descriptors: Prostitution; Health Vulnerability; Knowledge; Sexually Transmitted Diseases; Women's Health.

\footnotetext{
${ }^{1}$ Supported by Conselho Nacional de Desenvolvimento Científico e Tecnológico (CNPq) and by Ministério da Educação.

${ }^{2}$ Doctoral student, Faculdade de Medicina, Universidade Federal de Goiás, Goiânia, GO, Brazil. Assistant Professor, Faculdade de Enfermagem, Universidade Federal de Goiás, Goiânia, GO, Brazil.

${ }^{3}$ Doctoral student, Faculdade de Medicina, Universidade Federal de Goiás, Goiânia, GO, Brazil.

${ }^{4}$ Master's student, Faculdade de Enfermagem, Universidade Federal de Goiás, Goiânia, Go, Brazil.

${ }^{5}$ MSc, RN, Secretaria Municipal de Saúde de Jataí, Jataí, GO, Brazil.

${ }^{6} \mathrm{PhD}$, Associate Professor, Faculdade de Enfermagem, Universidade Federal de Goiás, Goiânia, GO, Brazil.
}

Corresponding Author:

Marcos André de Matos

Universidade Federal de Goiás. Faculdade de Enfermagem

Rua 227, s/n

Quadra 68

Bairro: Leste Universitário

CEP: 74080-605, Goiânia, GO, Brasil

E-mail: marcosdeminas@yahoo.com.br 


\section{Introduction}

It is estimated that one million people acquire sexually transmitted diseases (STDs) every day, including the human immunodeficiency virus (HIV). Young adults and adolescents account for half of all new STD cases $^{(1-2)}$. Currently, STDs represent a considerable public health problem, and their prevalence is greater among populations that exhibit high-risk behaviors, such as users of illegal drugs, men who have sex with men, and female sex workers (FSWs) ${ }^{(2-4)}$.

FSWs are considered a high-risk population for STDs. Many FSWs use legal or illegal drugs and have sex without condoms. In addition, they exhibit individual, social, and structural vulnerabilities, such as low educational levels, geographic mobility, difficulty accessing healthcare services, gender-related hindrances, and social stigma ${ }^{(5-8)}$.

Some studies have found high STD rates among FSWs. A meta-analysis that included 99,878 FSWs from 51 countries found an HIV prevalence of $11.8 \%{ }^{(9)}$. In a five-year study of a cohort of 3,086 women from Indonesia, the prevalence rates of gonorrhea and syphilis increased from $11.0 \%$ to $19.0 \%$ and from $1.4 \%$ to $5.1 \%$, respectively. A multicenter study conducted with 2,523 FSWs from nine Brazilian states and the Federal District found prevalence rates of $4.9 \%$ and $2.5 \%$ for HIV infection and syphilis, respectively(10). In São Paulo(11), the prevalence of human papillomavirus (HPV) was $67.7 \%$, while the prevalence of chlamydial infections was $20.5 \%$, syphilis was $4.0 \%$, and trichomoniasis was $3.0 \%$.

The Brazilian Midwest is an important area for prostitution and international trafficking of women ${ }^{(12-13)}$. Because of its geographic location, it functions as a supplier or transit area for the sex industry. Thirty percent of the 131 international women trafficking routes pass through the central area of Brazil. The city of Goiania is considered an important center of prostitution and sexual tourism. It is currently a nationally known prostitution center and the Brazilian town where child prostitution is growing most rapidly. Evidence indicates that services related to sex tourism in Goiania are expanding (e.g., there was a 300\% increase in nightclubs between 2002 and 2008)(12-13).

FSWs might function as true disseminators of STDs within their work and social environments and thus contribute to the endemic nature of these conditions. To date, no studies on STDs among FSWs from Goiania have been conducted, despite this group's vulnerability to these diseases. Because formulating strategies for STD prevention requires thorough knowledge of the target population's vulnerability profile, the aim of the present study was to investigate the knowledge of STDs, the risk behaviors, and the presence of STD signs/ symptoms among FSWs.

\section{Methods}

A cross-sectional study was conducted in Goiania (GO) in central Brazil from May 2009 to June 2010 with female prostitutes who work in public (e.g., streets, avenues, squares, parks) and private (e.g., nightclubs, brothels, cinemas) areas. The sample size was calculated based on a $7 \%$ minimum prevalence ${ }^{(2)}, 80 \%$ statistical power $(\beta=20 \%)$, a $95 \%$ significance level, $p$ $(<0.05), 3.5 \%$ error, a $2.0 \%$ design effect, and a $15 \%$ safety margin, which resulted in 395 participants. The inclusion criteria were age above 18 years, exchanging sex for money, performing prostitution in Goiania, and exhibiting a valid recruitment ticket at the time of the interview. The exclusion criterion was self-reported transgender status.

Because the population of FSWs is difficult to access, we used respondent-driven sampling (RDS), a sampling method that can generate probabilistic samples and is particularly recommended for difficultto-access populations ${ }^{(7,14)}$. RDS is a variant of the chainreferral method and has been used in several countries, including Brazil(7,15-16). The use of RDS is based on a referral made by peers and requires social networks that connect the target population ${ }^{(7,16)}$.

The RDS process began with the non-random selection of a small number of volunteers from the target population who were designated as "seeds". The selection and recruitment of "seeds" was based on a formative study conducted in May and June 2009. That study identified the areas where prostitution is performed in Goiania, key FSWs, data collection sites, and compensation types. That stage of the research was supported by civil society organizations that target FSWs in Goiania.

Seven "seeds" were invited to participate in the study. The characteristics of these key FSWs are described in table I. Each "seed" was asked to bring three FWSs with whom they were acquainted to the study. They were given three personal invitations/tickets to give to their invited peers, and thus, the first "wave" of the study was launched. The FSWs recruited by the "seeds" were also given three validated tickets to invite 
their acquaintances and friends who were FSWs (second wave) and so forth, until the estimated sample size was attained (395).

All of the eligible women who presented a ticket/ invitation were informed about the study aims and procedures, read and signed an informed consent form, and then were interviewed with a structured script that included questions about sociodemographic data (age, education level, ethnicity, religion, provenance, marital status, head of household), professional practice (work place and schedule, health care), knowledge about STDs and signs/symptoms of STDs/HIV/acquired immune deficiency syndrome (AIDS) according to the World Health Organization's (WHO) syndrome-based approach (abdominal pain, pain and burning upon urinating, groin swelling, genital wounds/ulcers, and itching), which classifies diseases under pre-set syndromes based on the signs and symptoms ${ }^{(2)}$.

The data analysis was performed using the statistical software packages SPSS version 15.0 for Windows and RDSAT v.5.6. The latter enabled us to analyze the characteristics of the investigated population with $95 \%$ confidence intervals (CIs) as a function of the recruitment patterns and the network size relative to the other participants, taking the sample homophily and the variable balance reach into consideration(16-17). The study was analyzed and approved by the Human and Animal Medical Research Ethics Committee of the Clinical Hospital of the Federal University of Goiás (Comitê de Ética em Pesquisa Médica Humana e Animal do Hospital das Clínicas da Universidade Federal de Goiás - CEPMHA/ HC/UFG protocol no. 001/9).

Table 1 - Characteristics of the seven non-randomly selected "seeds", Goiania, GO, Brazil, 2009-2010

\begin{tabular}{|c|c|c|c|c|c|c|c|c|}
\hline Seeds & $\begin{array}{l}\text { Prostitution } \\
\text { site type }\end{array}$ & $\begin{array}{c}\text { Work } \\
\text { schedule }\end{array}$ & Age & $\begin{array}{c}\text { No. } \\
\text { years of } \\
\text { schooling }\end{array}$ & $\begin{array}{c}\text { State of } \\
\text { provenance }\end{array}$ & Religion & Skin color & $\begin{array}{l}\text { Marital } \\
\text { status }\end{array}$ \\
\hline 1 & Public places & Both & 53 & 4 & GO & Catholic & White & Separated \\
\hline 2 & Public places & Both & 38 & 2 & GO & Evangelical & Brown & Single \\
\hline 3 & Public places & Daytime & 50 & 7 & MG & None & Brown & Single \\
\hline 4 & Private residence - Brothel & Both & 34 & 13 & GO & None & Brown & Separated \\
\hline 5 & Nightclub - Brothel & Both & 28 & 11 & GO & Catholic & Brown & Single \\
\hline 6 & Public places & Both & 37 & 12 & MA & Evangelical & White & Separated \\
\hline 7 & Movie theater & Daytime & 34 & 6 & GO & Evangelical & Other & Single \\
\hline
\end{tabular}

\section{Results}

With regard to the sociodemographic characteristics of the 395 FSWs in the sample, most of the participants (70.1\%) were younger than 30 years. Only $18.3 \%$ were 31 to 40 years old, and $11.6 \%$ were older than 40 years old. Approximately $51.3 \%$ reported having nine years of schooling or less, $47.3 \%$ reported 10 to 12 years, and $2.3 \%$ reported more than 13 years. The prevailing selfreported skin color was brown $(59.5 \%)$, followed by white $(27.3 \%)$, and black $(12.5 \%)$. Only $17.2 \%$ of the women reported that they did not practice any religion; $59.9 \%$ were Catholic, $18.8 \%$ were evangelical, and $4.0 \%$ were spiritist. Approximately $67.1 \%$ of the women were single, $15.7 \%$ were married, $14.4 \%$ were separated, and $2.9 \%$ were widows. Approximately $70 \%$ reported that the revenue from prostitution helped to support other people.

Table 2 describes the participants' knowledge on the signs and symptoms of STDs. Genital wounds/ulcers $(66.6 \%)$ and itching $(61.6 \%)$ were the most widely recognized STD signs/symptoms, followed by pain and burning upon urination (57.1\%) and abdominal pain. Conversely, groin swelling was recognized as a sign of an STD by only one-third of the volunteers.

Table 2 - Knowledge of STD signs/symptoms according to the WHO's syndromic approach among 395 female sex workers from Goiania, GO, Brazil, 2009-2010

\begin{tabular}{lccc}
\hline \multirow{2}{*}{$\begin{array}{c}\text { STD signs/symptoms } \\
\text { in women }\end{array}$} & \multicolumn{2}{c}{ RDS $^{*}$} & $\mathbf{n}$ \\
\cline { 2 - 3 } & $\begin{array}{c}\text { Adjusted } \\
\text { estimate (\%) }\end{array}$ & $95 \% \mathrm{Cl}$ & \\
\hline Abdominal pain & 21.5 & $13.4-28.1$ & 84 \\
No & 48.7 & $37.9-59.1$ & 217 \\
Yes & 29.8 & $19.8-43.6$ & 94 \\
Do not know & & & \\
Pain and burning upon & & & \\
urination & 8.2 & $4.0-11.9$ & 39 \\
No & 57.1 & $45.2-68.3$ & 259 \\
Yes & 34.7 & $23.4-48.4$ & 97 \\
Do not know & & & (continue...)
\end{tabular}


Table 2 - (continuation)

\begin{tabular}{lccc}
\hline \multirow{2}{*}{$\begin{array}{c}\text { STD signs/symptoms women } \\
\text { in }\end{array}$} & \multicolumn{2}{c}{$\begin{array}{c}\text { Adjusted } \\
\text { estimate (\%) }\end{array}$} & 95\% CI \\
\hline Groin swelling & 14.4 & $6.7-19.3$ & 80 \\
No & 33.8 & $20.4-47.7$ & 204 \\
Yes & 51.8 & $37.0-70.3$ & 111 \\
Do not know & 10.7 & $6.0-16.1$ & 33 \\
Genital wounds/ulcers & 66.6 & $58.2-76.5$ & 283 \\
No & 22.7 & $13.1-31.2$ & 79 \\
Yes & & & \\
Do not know & 9.5 & $4.5-14.5$ & 27 \\
Itch & 61.4 & $50.0-71.5$ & 275 \\
No & 29.1 & $19.3-41.4$ & 93 \\
Yes & & & \\
Do not know & & & \\
\hline * Estimates adjusted for recruitment patterns in RDSAT. $\mathrm{n}=395$ & \\
\hline
\end{tabular}

With regard to the participants' knowledge about HIV/AIDS, Table 3 shows that most of the women knew that healthy-looking people might be HIV carriers $(91.7 \%)$, that the use of condoms protects against infection $(80.7 \%)$, that HIV might be transmitted by sharing contaminated needles/syringes (99.0\%), and that infected women might transmit the virus to the baby during pregnancy/labor $(90.6 \%)$ or by breastfeeding (70.5\%). Approximately $19.0 \%$ of the interviewees did not endorse condom use as a method of preventing HIV infection. Approximately $81.4 \%$ of the volunteers reported that they did not believe that sexual abstinence might prevent HIV infection. Approximately $37.4 \%$ of the participants indicated mosquito bites and $17.4 \%$ indicated shared silverware as possible paths of HIV infection.

Whereas 357 (90.6\%) volunteers knew that HIV can be transmitted during pregnancy, $23.9 \%$ did not know it can also occur during breastfeeding, and more than half $(59.4 \%)$ had no knowledge about prophylaxis for vertical transmission.

Table 3 - Knowledge about HIV/AIDS among 395 female sex workers from Goiania, GO, Brazil, 2009-2010

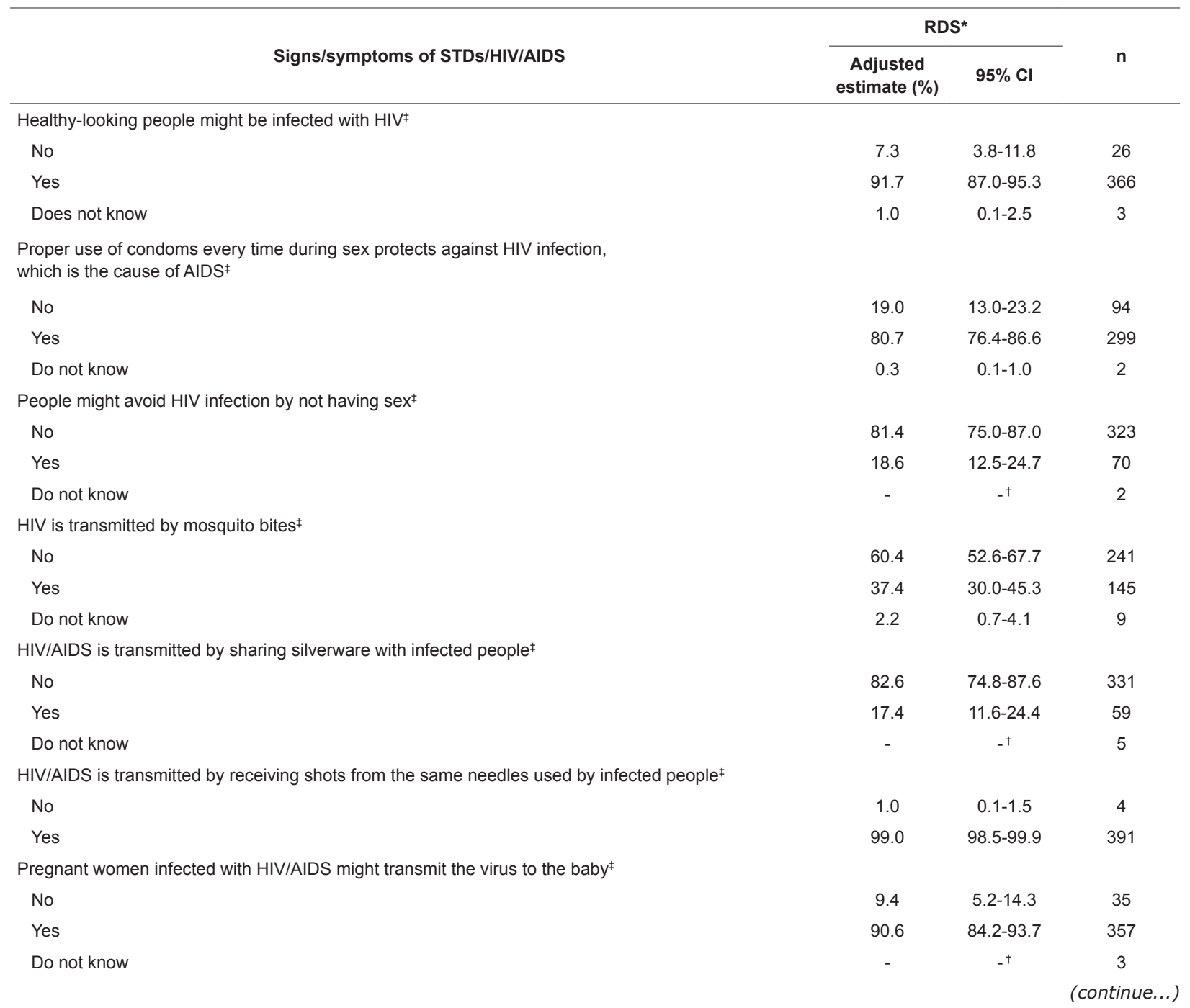


Table 3 - (continuation)

\begin{tabular}{|c|c|c|c|}
\hline \multirow[b]{2}{*}{ Signs/symptoms of STDs/HIVIAIDS } & \multicolumn{2}{|c|}{ RDS* $^{*}$} & \multirow[b]{2}{*}{$\mathbf{n}$} \\
\hline & $\begin{array}{c}\text { Adjusted } \\
\text { estimate (\%) }\end{array}$ & $95 \% \mathrm{Cl}$ & \\
\hline \multicolumn{4}{|l|}{$\begin{array}{l}\text { Pregnant women infected by HIVIAIDS might reduce the risk of transmitting } \\
\text { the virus to the baby when they§ }\end{array}$} \\
\hline Use medication & 40.6 & $32.4-47.9$ & 166 \\
\hline Other & 13.9 & $9.0-19.6$ & 55 \\
\hline Do not know & 45.5 & $38.3-54.1$ & 172 \\
\hline \multicolumn{4}{|l|}{ HIVIAIDS might be transmitted to babies through breastfeeding ${ }^{\ddagger}$} \\
\hline No & 23.9 & $17.6-31.6$ & 92 \\
\hline Yes & 70.5 & $62.6-76.9$ & 269 \\
\hline Do not know & 5.6 & $3.4-8.6$ & 34 \\
\hline
\end{tabular}

*Estimates adjusted for recruitment patterns in RDSAT. +RDSAT did not generate a confidence interval.

$\neq n=395 . \S n=393$

The signs and symptoms of STDs according to the WHO's syndromic approach reported by the interviewees are described in table IV. Vaginal discharge and wounds/ ulcers in the past 12 months were reported by $49.0 \%$ and $8.6 \%$ of the participants, respectively, but $41.7 \%$ had not sought treatment at health care facilities.

Table 4 - Signs/symptoms of STDs according to the WHO's syndromic approach reported by 395 female sex workers from Goiania, GO, Brazil, 2009-2010

\begin{tabular}{|c|c|c|c|}
\hline \multirow[b]{2}{*}{ Variable } & \multicolumn{2}{|c|}{ RDS $^{*}$} & \multirow[b]{2}{*}{$n$} \\
\hline & $\begin{array}{c}\text { Adjusted } \\
\text { estimate (\%) }\end{array}$ & $95 \% \mathrm{Cl}$ & \\
\hline \multicolumn{4}{|c|}{$\begin{array}{l}\text { Vaginal discharge in the } \\
\text { past } 12 \text { months }^{\dagger}\end{array}$} \\
\hline No & 51.0 & $43.5-59.0$ & 200 \\
\hline Yes & 49.0 & $41.0-56.5$ & 195 \\
\hline \multicolumn{4}{|c|}{$\begin{array}{l}\text { Genital wounds or ulcers } \\
\text { in the past } 12 \text { months }^{\dagger}\end{array}$} \\
\hline No & 91.4 & $87.2-94.8$ & 356 \\
\hline Yes & 8.6 & $5.2-12.8$ & 39 \\
\hline \multicolumn{4}{|c|}{$\begin{array}{l}\text { Sought treatment from } \\
\text { health care services }{ }^{\ddagger}\end{array}$} \\
\hline No & 41.7 & $24.8-54.0$ & 37 \\
\hline Yes & 58.3 & $46.0-75.2$ & 69 \\
\hline
\end{tabular}

*Estimates adjusted for recruitment patterns in RDSAT

$+n=395$

$\neq \mathrm{n}=106$

\section{Discussion}

Assessing the presence of signs/symptoms of STDs and the knowledge about STDs among difficult-toaccess groups such as FSWs is necessary to formulate, implement, and assess public health policies focusing on the control and prevention of STD/HIV/AIDS.

The investigated population comprised mostly young and single women, which is typical for FSWs in
Brazil $^{(7)}$ and other countries ${ }^{(3,9)}$. Compared with other study populations(18-19), however, the present sample from Goiania had a higher level of education: more than half of the participants had attended school for 10 or more years. This finding might reflect the education indexes in our area. According to the 2009 National Household Sample Survey (Pesquisa Nacional por Amostra de Domicílio - PNAD), about half the economically active population in the Midwest of Brazil has at least 11 years of schooling(20).

Nonetheless, the lack of knowledge on the signs/symptoms of STDs exhibited by the FSWs was considerable. Over one-third of the participants reported that abdominal pain, pain and burning upon urination, groin swelling, genital wounds/ulcers, and itching (symptoms following the WHO's syndromic approach) were not associated with STDs or that they did not know ${ }^{(2)}$. These findings align with the findings of previous studies ${ }^{(9,21)}$ and point to the urgent need for greater investment in health education strategies focusing on FSWs' ability to identify the signs and symptoms of STDs to encourage early diagnoses, to improve prognoses, and to interrupt the transmission chain of these pathogens.

With regard to the transmission pathways of HIV, although almost all of the interviewees stated that healthy-looking people might be infected with HIV $(91.7 \%)$ and that sharing syringes and needles to administer injectable drugs might transmit the virus (99.0\%), some misconceptions about this topic persist.

One out of five participants in the present study did not consider condom use a method for preventing HIV. According to a meta-analysis, data on FSWs' perceptions of their vulnerability to STDs and the use of barrier methods are still scarce, indicating an urgent need to broaden access to prevention programs ${ }^{(9)}$. Some myths 
about HIV transmission persist among FSWs; many of these myths can be traced back to the beginning of the HIV/AIDS epidemic in the 1980s (e.g., transmission via silverware sharing and mosquito bites). These findings were also reported in a multicenter study conducted by the Health Ministry ${ }^{(22)}$.

More than half of the volunteers $(59.4 \%)$ had no knowledge about preventing the vertical transmission of HIV, and $23.9 \%$ did not know that transmission can occur through breastfeeding. Because most of the volunteers were in the fertile age range, investing in the Integrated Plan to Confront the Feminization of the AIDS Epidemic and other STDs (Plano Integrado de Enfrentamento da Feminização da Epidemia da Aids e outras DST) must be a priority; one of its aims is to reduce the vertical transmission of HIV in the entire female population ${ }^{(1)}$.

In the present study, an STD was defined as selfreported vaginal discharge and a wound/ulcer in the past 12 months, whether or not these symptoms were associated with a past medical/laboratory diagnosis of an STD, following the WHO's syndromic approach(2). Vaginal discharge was reported by $49.0 \%$ of the volunteers, and wounds/ulcers were reported by $8.6 \%$. These findings align with the STD prevalence rates reported in previous studies $^{(21,23-24)}$.

Among the participants who reported signs/ symptoms of STDs, a considerable fraction (41.7\%) had not sought treatment from health care services, providing additional evidence that this population is removed from the formal health care system because of their social exclusion (23-24). Studies on STD knowledge, risk behaviors, and self-reported STD symptoms are important tools for formulating effective action plans and STD prevention for difficult-to-access populations. Because they are invisible to the health care system and are socially marginalized and stigmatized, they contribute significantly to the dissemination of these illnesses.

The findings of the present study contribute to the scientific knowledge in the field by improving the understanding of the epidemiology of STDs in a target population for prevention efforts.

\section{Conclusions}

The investigated population comprised young adult FSWs who were single and had a low education level. The volunteers exhibited poor knowledge about HIV transmission and the signs and symptoms of STDs, indicating that the investigated population is highly vulnerable to STDs. The prevalence of self-reported vaginal discharge was $49.0 \%$, and the prevalence of wounds/ulcers was $8.6 \%$. These figures align with the prevalence rates of STDs reported in previous studies conducted in Brazil and other countries and that confirm that FSWs potentially play a role in disseminating STDs.

\section{References}

1. Ministério da Saúde (BR). Boletim Epidemiológico Aids e DST 2011. Ano 8(1). Brasília (DF): Departamento de DST/HIV/AIDS e hepatites virais; 2011. $162 \mathrm{p}$.

2. World Health Organization, Department of Reproductive Health and Research. Global strategy for the prevention and control of sexually transmitted infections: 2006 2015. Breaking the chain of transmission. Washington; 2007.

3. Decker MR, Wirtz AL, Baral SD, Peryshkina A, Mogilnyi $V$, Weber RA, et al. Injection drug use, sexual risk, violence and STI/HIV among Moscow female sex workers. Sex Transm Infect Sex Trans. 2012;88(4):278-83.

4. Wang $K$, Yan $H$, Liu $Y$, Leng $Z$, Wang B, Zhao J. Increasing prevalence of HIV and syphilis but decreasing rate of self-reported unprotected anal intercourse among men who had sex with men in Harbin, China: results of five consecutive surveys from 2006 to 2010 . Int J Epidemiol. 2012;41(2):423-32.

5. Ayres JRCM, Calazans GJ, Saletti HC Filho, FrançaJúnior I. Risco, vulnerabilidade e práticas de prevenção e promoção da saúde. In: Campos GWS, organizador. Tratado de saúde coletiva. $2^{a}$ ed. São Paulo: Hucitec/Rio de Janeiro: Fiocruz; 2009. p. 375-417.

6. Figueiredo $R$, Peixoto M. Profissionais do sexo e vulnerabilidade. BIS, Bol Inst Saúde. 2010;12(2):1518812.

7. Damacena GN, Szwarcwald CL, Barbosa A Júnior. Implementação do método de amostragem respondentdrivensampling entre mulheres profissionais do sexo no Brasil, 2009. Cad Saúde Pública. 2011;27(1):45-55.

8. Nurlan SN, Davies SCSC, Kaldor JJ, Wignall SS, Okoseray MM. Prevalence over time and risk factors for sexually transmissible infections among newly-arrived female sex workers in Timika, Indonesia. Sex Health. 2011;8(1):61-4.

9. Baral S, Beyrer C, Muessig K, Poteat T, Wirtz AL, Decker MR, et al. Burden of HIV among female sex workers in low-income and middle-income countries: a systematic review and meta-analysis. Lancet Inf Diseases. 2012;12(7):538-49.

10. Szwarcwald CL. Taxas de prevalência de HIV e sífilis e conhecimento, atitudes e práticas de risco relacionadas 
às infecções sexualmente transmissíveis no grupo das mulheres profissionais do sexo. Tec Report Fiocruz, Brasil, 2010. [acesso 18 junho 2012]. Disponível em: http:// sistemas.aids.gov.br/prevencao2010/sites/default/files/ page/2010/18.06.2010/MR_CeliaLandmann.pdf.

11. Baldin-Dal Pogetto MR, Silva MG, Parada CMG. Prevalence of sexually transmitted diseases in female sex workers in a city in the interior of São Paulo, Brazil. Rev. Latino-Am. Enfermagem. 2011;19(3):493-9.

12. Ministério Público do Estado de Goiás (BR). Prostituição é atividade de 42 milhões de mulheres. Diário da Manhã [Internet]. 2012 [acesso 5 maio 2012]. Disponível em: http://www.mp.go.gov.br/portalweb/1/ noticia/eb7d046a02f08ce3651e09b6bdfad484.html.

13. Lima A, Silva J. Dinâmicas territoriais urbanas: a articulação do turismo eas profissionais do sexo em Goiânia - Goiás - Brasil. [acesso 8 maio 2012]. Disponível em: http://observatoriogeograficoamericalatina.org.mx/ egal12/Geografiasocioeconomica/Geografiaurbana/259. pdf.

14. Barbosa A Júnior, Pascom ARP, Szwarcwald $C L$, Kendall C, McFarland W. Transfer of sampling methods for studies on most-at-risk populations (MARPs) in Brazil. Cad Saúde Pública. 2011;27 Suppl 1:S36-44.

15. Kral AH, Malekinejad M, Vaudrey J, Martinez AN, Lorvick J, McFarland W, et al. Comparing RespondentDriven Sampling and Targeted Sampling Methods of recruiting injection drug users in San Francisco. J Urban Health. 2010;87(5):839-50.

16. Uuskula A, Johnston LG, Raag M, Trummal A, Talu A, Jarlais DCD. Evaluating recruitment among female sex workers and injecting drug users at risk for HIV using Respondent-driven Sampling in Estonia. J Urban Health. 2010;87(2):304-17.

17. Johnston JG, Sabin K. Sampling hard-to-reach populations with respondent driven sampling. Methodol Innovat Online. 2010;5(2):38-48.

18. Kriitmaa K, Testa A, Osman M, Bozicevic I, Riedner G, Malungu J, et al. HIV prevalence and characteristics of sex work among female sex workers in Hargeisa, Somaliland, Somalia. AIDS 2010;24(6):61-67.

19. Mahfoud Z, Afifi R, Ramia S, Khoury DE, Kassak K, Barbir FE, et al. HIV/AIDS among female sex workers, injecting drug users and men who have sex with men in Lebanon: results of the first biobehavioral surveys. AIDS. 2010; 24(6):45-54.

20. Instituto Brasileiro de Geografia e Estatística (IBGE). Pesquisa Nacional por Amostra de Domicílios (PNAD) Síntese de Indicadores 2009. Brasília (DF): Ministério do Planejamento Orçamento e Gestão; 2010. 620 p. Relatório final.

21. Seib C, Debattista J, Fischer J, Dunne M, Najman JM. Sexually transmissible infections among sex workers and their clients: variation in prevalence between sectors of the industry. Sexual Health. 2009;6(1):45-50.

22. Ministério da Saúde (BR). Secretaria de Vigilância em Saúde. Programa Nacional de DST e Aids. Série Estudos Pesquisas e Avaliação. Avaliação da efetividade das ações de prevenção dirigidas às profissionais do sexo, em três regiões brasileiras. Brasília (DF); 2004. v. 7, $104 \mathrm{p}$.

23. Pando $M A$, Berini $C$, Fernandez $M$, Reinaga $E$, Maulen S, Marone $\mathrm{R}$, et al. Prevalence of HIV and other sexually transmitted infections among female commercial sex workers in Argentina. Am J Trop Med Hyg. 2006;74(2):233-8.

24. Xu JJ, Ning W, Lin L, Yi P, Lei GZ, Michelle W, et al. HIV and STIs in clients and female sex workers in mining regions of Gejiu City, China. Sex Transm Dis. 2008;35(6):558-65. 